\title{
Types of particles recovery-water recovery entrainment plots useful in flotation research
}

\author{
Zaklina Konopacka · Jan Drzymala
}

Received: 16 March 2010 / Accepted: 15 June 2010 / Published online: 10 July 2010

(C) The Author(s) 2010. This article is published with open access at Springerlink.com

\begin{abstract}
This review paper deals with graphical representation of entrainment experienced by fine particles during passing, either barren or mineralized, bubbles through flotation cells. Entrainment, also called mechanical carryover or mechanical flotation, is harmful because it reduces the quality of flotation concentrates. It was presented in the paper that it is convenient to show the results of entrainment as upgrading separation plots relating recovery of fines vs. water recovery. The shape of the entrainment separation curves significantly depends on the way flotation test is performed, type of flotation machine, kinetics of process, froth collecting time, concentration of frothers, collectors and modifiers, amount of air in flotation, density of pulp, amount of supplied water etc. Five types of entrainment separation plots were distinguished and presented in the paper. They were categorized as linear (type 1), linear shifted down (type 2), reaching plateau (type 3), increasing (type 4) and linear shifted up (type 5). The plots are useful for determination of appropriate entrainment coefficients characterizing the process.
\end{abstract}

Keywords Entrainment - Mechanical carryover . Mechanical flotation $\cdot$ Froth flotation

Paper is devoted to honor the memory of professor A. Waksmundzki on the 100th anniversary of his birth.

Z. Konopacka · J. Drzymala $(\bowtie)$

Wroclaw University of Technology, Wybrzeze Wyspianskiego 27, 50-370 Wroclaw, Poland

e-mail: jan.drzymala@pwr.wroc.pl

\section{Introduction}

Bubbling gases through solutions and flotation of hydrophobic particles are accompanied by entrainment of particles. The entrainment is experienced by hydrophobic and hydrophilic particles. The entrainment is also called mechanical carryover and mechanical flotation and occurs without a direct attachment of particle to the bubble. Entrainment results from different phenomena which are schematically shown in Fig. 1.

One of the pioneers investigating entrainment of hydrophilic fines during flotation of hydrophobic particles was professor A. Waksmundzki. In the paper with NeczajHruzewicz and Ptanik published in 1972 in the Institution of Mining and Metallurgy journal they investigated entrainment of marble particles during flotation of elemental sulfur with $\alpha$-terpineol as the frother and dodecane as collector. They established a linear correlation between recovery of marble fines and the thickness of water on bubbles. The water thickness was regulated with $\alpha$-terpineol concentration. Since the surface area of bubbles in a given flotation can be assumed to be constant, the thickness of water layer around bubbles is also a measure of the volume of entrained water. Their results are shown in Fig. 2.

Figure 2 indicates that, to a great extent, the recovery of hydrophilic fine marble particles is proportional to the amount of water collected with the floating bubbles. A small shift to the right of the approximation line in relation to the origin of the plot is also visible.

Since publication of papers on entrainment by professor Waksmundzki and his co-workers (Waksmundzki et al. 1972; Wojcik et al. 1973) other works dealing with fine particles entrainment have been published, for instance by Lynch et al. (1974, 1981), Engelbrecht and Woodburn (1975), Bisshop and White (1976), Trahar (1981), Warren 


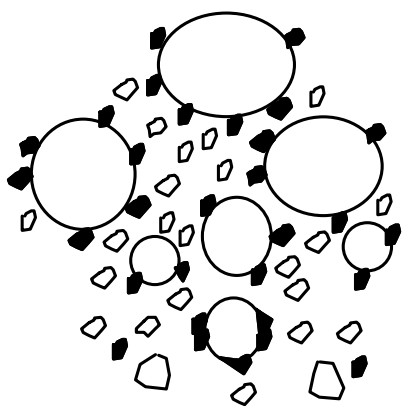

(a)

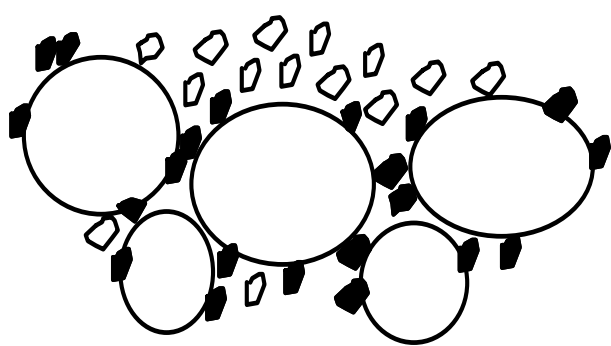

(c)

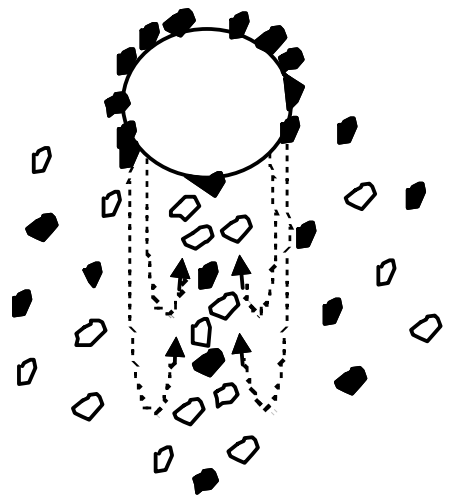

(e)

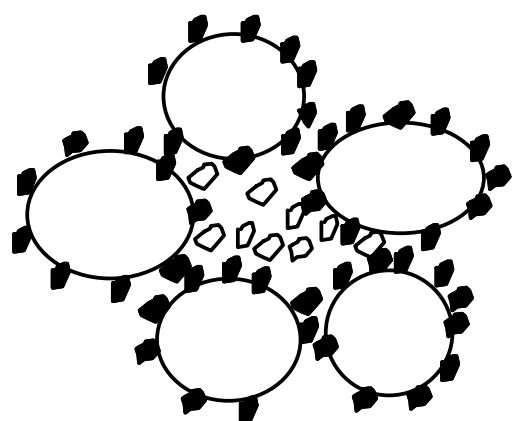

(b)

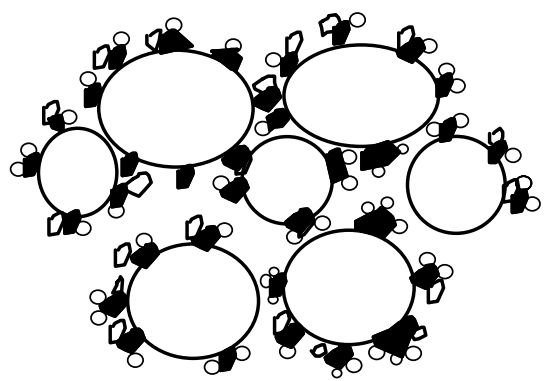

(d)

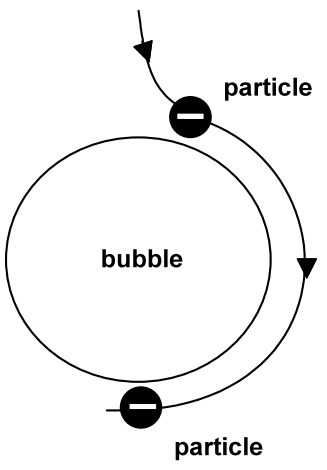

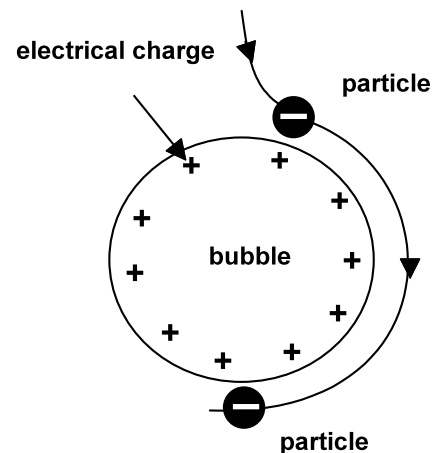

ii

(f)

Fig. 1 Mechanical flotation is caused by (a) carrying upwards in Plateau regions, (b) entrapment, (c) supporting, (d) slime coating, (e) waking, (f) contactless flotation (due to dispersive (i) and dispersive + polar (ii) forces). After Konopacka (2005)

(1985), Ross and Van Deventer (1988), Subrahmanyam and Forssberg (1988a, 1988b), Kirjavainen (1989, 1992a, 1992b, 1996), Kirjavainen et al. (1991), Ross (1991a, 1991b), Maachar and Dobby (1992), Drzymala and Hrycyna (2004), Konopacka (2005), and other authors. Earlier this subject was investigated by Jowett (1966) and Livshits and Bezrodnaya (1961).

A careful analysis of data on mechanical flotation by Konopacka $(2004,2005)$ indicated that this phenomenon is influenced by such parameters as density, size and shape of particles, geometry of flotation machine, properties of froth and method of flotation. She also showed that entrainment can be treated as any other separation process and presented it in a form of upgrading curves relating quality and quantity of flotation products taking into account entrainment of particles and water. The Fuerstenau upgrading plot seems to be the most useful (Drzymala and Ahmed 2005). It relates recovery of entrained particles $\varepsilon_{s}$ and recovery of water $\varepsilon_{w}$ in the floating product. Her detailed analysis of entrainment showed that there are 5 types of the particles recovery vs. water recovery entrainment curves which are shown in Fig. 3.

As it has already been mentioned, the shape of the entrainment curves depends on many factors. The most crucial are: way of performing experiments and type of flotation (batch or continuous). Among the continuous flotation 


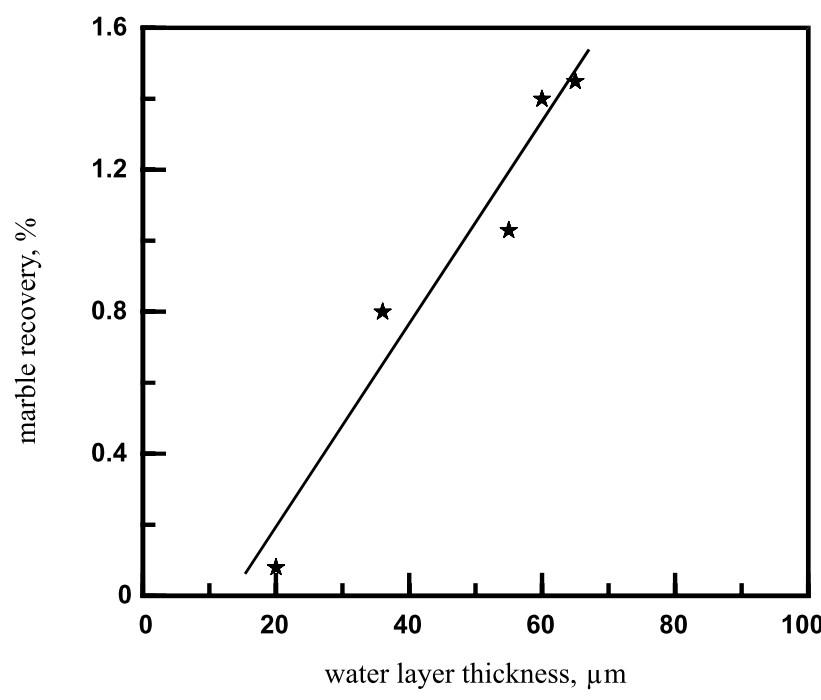

Fig. 2 Fine marble particles recovery as a function of water thickness on bubbles, regulated with $\alpha$-terpineol concentration (frother) during flotation of artificial sulfur-marble mixture in the presence of $770 \mathrm{~g} / \mathrm{Mg}$ dodecane as collector (after Waksmundzki et al. 1972)

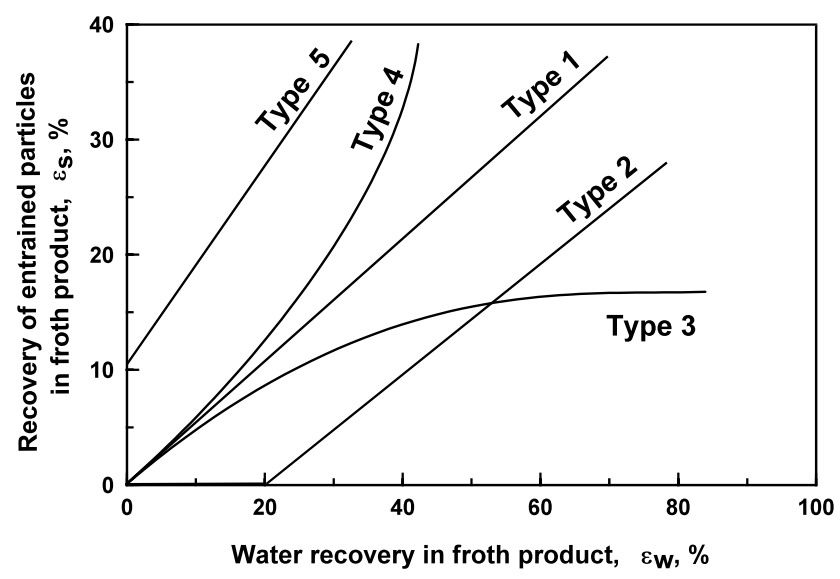

Fig. 3 Shapes of entrainment plots in the Fuerstenau upgrading separation plot

processes there is flotation with a constant supply of the feed and formation of two products (concentrate and tailing). The batch flotation can be performed without adding anything to the flotation cell during the process, with recirculation of the concentrate, with recirculation of aqueous solution, as well as with water addition to keep the pulp level constant. In the latter case, water recovery can be greater than $100 \%$ of the initial amount of water. The shape of the entrainment curves also depends on the velocity and time of froth product collection, froth properties regulated with frother dose, velocity of air supply, and flotation type.

The five types of entrainment separation curves can be classified into linear (type 1), linear shifted down (type 2), increasing with plateau (type 3 ), increasing (type 4) and lin-

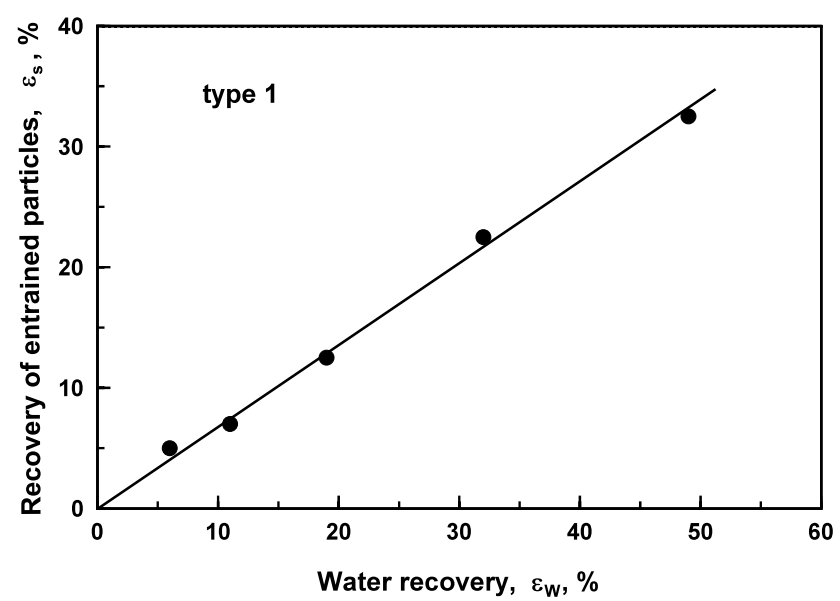

Fig. 4 Entrainment of quartz $(<5 \mu \mathrm{m})$ observed for $27 \%$ solids content in the feed in the presence of PPG 400 frother. After Trahar (1981)

ear shifted up (type 5). All the types will be characterized in the following sections.

\section{Types of entrainment separation curves}

\subsection{Type 1}

A linear character of the entrainment separation curve plotted in the form of recovery of fine particles $\varepsilon_{s}$ versus water recovery $\varepsilon_{w}$ in concentrate, which starts from the origin of the graph, was reported by Livshits and Bezrodnaya (1961), and later by Trahar (1981) (Fig. 4), Subrahmanyam and Forssberg (1988b) as well by Engelbrecht and Woodburn (1975).

According to Warren (1985), entrainment of fines, when recovery of particles is linearly proportional to water recovery (type 1 of mechanical flotation) can be characterized with the formula

$\varepsilon_{s}=e \cdot \varepsilon_{w}$

where $e$ denotes dimensionless entrainment coefficient (independent on $\varepsilon_{s}$ and $\left.\varepsilon_{w}\right), \varepsilon_{s}$ recovery of entrained particles in froth product $\left(\varepsilon_{s}=\frac{\left(m_{s}\right)_{C}}{\left(m_{s}\right)_{F}} \cdot 100 \%\right), \varepsilon_{w}$ recovery of entrained water in froth product $\left(\varepsilon_{w}=\frac{\left(m_{w}\right)_{C}}{\left(m_{w}\right)_{F}} \cdot 100 \%\right), m_{s}$ and $m_{w}$ mass of particles and water, respectively (in mass units), $C$ concentrate, and $F$ stands for feed.

Since the recovery of particles is smaller than that of water, the values of coefficient $e$ are in the range from 0 to 1 .

Subrahmanyam and Forssberg (1988a, 1988b) investigated the values of $e$ for different sizes of hydrophilic particles collected in the froth product in different flotation cells. Their values are given in Table 1 .

There are many variations of entrainment coefficients $e$. It results from the fact that in (1) the amount of particles 
Table 1 Entrainment coefficient $e$ determined from the relation $e=\varepsilon_{s} / \varepsilon_{w}$ for different materials (after Subrahmanyam and Forssberg 1988a)

* In the original work of Trahar (1981) $e=0.72$ for quartz was determined for $<5 \mu \mathrm{m}$ particles

\begin{tabular}{llll}
\hline Material & Value of coefficient $e$ & Particie size $d[\mu \mathrm{m}]$ & $\begin{array}{l}\text { Source of data used by } \\
\text { Subrahmanyam and Forssberg (1988a) }\end{array}$ \\
\hline Quartz & 0.72 & $3.5^{*}$ & Trahar (1981) \\
Cassiterite ore & 0.85 & $<5.0$ & Goodman and Trahar (1977) \\
Silica & 0.99 & $<12.0$ & Engelbrecht and Woodburn (1975) \\
Bituminous coal & 1.00 & $<38.0$ & Lynch et al. (1981) \\
Quartz & 0.10 & $<40.0$ & Engelbrecht and Woodburn (1975) \\
Fine gangue & 0.87 & & Warren (1985) \\
Fine gangue & 0.78 & $<40.0$ & Subrahmanyam and Forssberg (1988a) \\
\hline
\end{tabular}

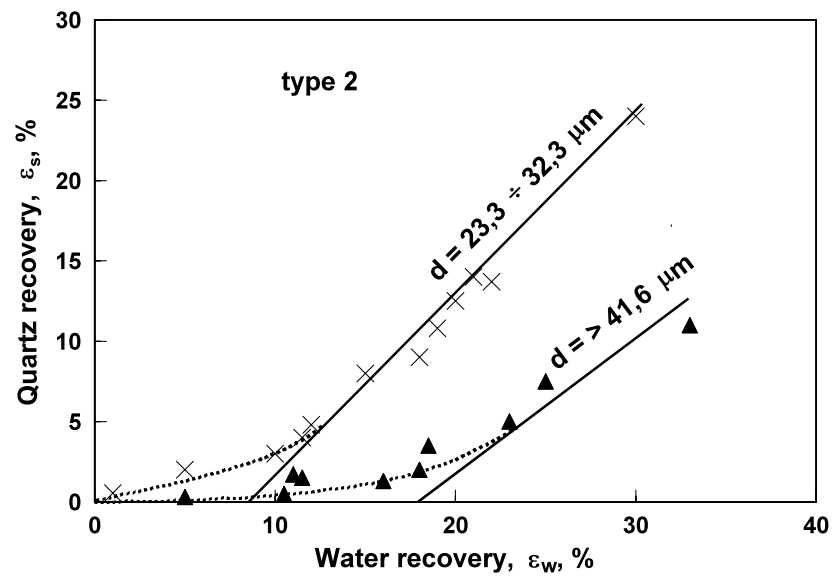

Fig. 5 Recovery of different size quartz particles as a function of water recovery obtained in the presence of Dowfroth 250 frother. Continuous flotation performed in a flotation machine equipped with flotation cell of $30 \mathrm{dm}^{3}$ in volume (Engelbrecht and Woodburn 1975)

and water can be expressed in different units, that is in percent, mass units, as streams in mass/time units. Therefore, this coefficient is called differently by various authors. Most frequently it is called entrainment factor (Warren 1985; Smith and Warren 1989).

\subsection{Type 2}

Sometimes the entrainment presented as $\varepsilon_{s}$ versus $\varepsilon_{w}$ forms a linear relationship but the line is shifted in relation to the origin of the plot (Waksmundzki et al. 1972; Engelbrecht and Woodburn 1975; Lynch et al. 1981). This is type 2 of the entrainment separation curve (Figs. 3 and 5). It usually happens when the feed contains coarse particles and the height of froth is low. This leads to separation of particles from the froth. Smith and Warren (1989) used a linear equation to relate $\varepsilon_{s}$ and $\varepsilon_{w}$ adding a correction factor shifting the line down in relation to $\left(\varepsilon_{w, 0}\right)$. The relation is:

$\varepsilon_{s}=f\left(\varepsilon_{w}-\varepsilon_{w, 0}\right)$
Table 2 Values of $f$ and $\varepsilon_{w, 0}$ for quartz subjected to mechanical entrainment in a flotation machine equipped with flotation cell of $30 \mathrm{dm}^{3}$ in volume in the presence of Dowfroth 250 (Engelbrecht and Woodburn 1975)

\begin{tabular}{lll}
\hline$f$ & $\varepsilon_{w, 0,} \%$ & $d, \mu \mathrm{m}$ \\
\hline 0.64 & 12.8 & +41.6 \\
0.93 & 7.1 & $23.3-32.3$ \\
1.0 & $\approx 0$ & -12 \\
\hline
\end{tabular}

and consists of two adjustable parameters, that is $\varepsilon_{w, 0}$ and $f$. Thus, the entrainment $f$ is given by:

$f=\frac{\varepsilon_{s}}{\varepsilon_{w}-\varepsilon_{w, 0}}$

where $\varepsilon_{w, 0}$ is the initial water recovery (in \%).

Typical values of $\varepsilon_{w, 0}$, along with $f$ values for quartz, are given in Table 2 .

\subsection{Type 3}

Another type of relation between $\varepsilon_{s}$ and $\varepsilon_{w}$ for entrainment of particles during flotation is represented by increasing curves which finally reach plateau. It will be called type 3 of entrainment separation curve. This type of entrainment curve usually occurs when the concentration of frother is small and the feed contains coarse particles. Also batch flotation, with either re-circulating or continuously added water to keep the water level in the flotation cell constant, provides such curves. Type 3 of entrainment separation curve for batch quartz flotation with water addition is shown in Fig. 6 and in Fig. 7 for flotation with recirculation of the froth product.

Type 3 of the entrainment separation curve was observed by Kirjavainen $(1989,1992 a, 1992 b)$ not only for quartz but also for chromite and phlogopite. He carried out his experiments in a laboratory Denver flotation machine of $3 \mathrm{dm}^{3}$ in volume. Similar relations were observed by Trahar (1981) as well as by Drzymala and Hrycyna (2004). Kirjavainen 


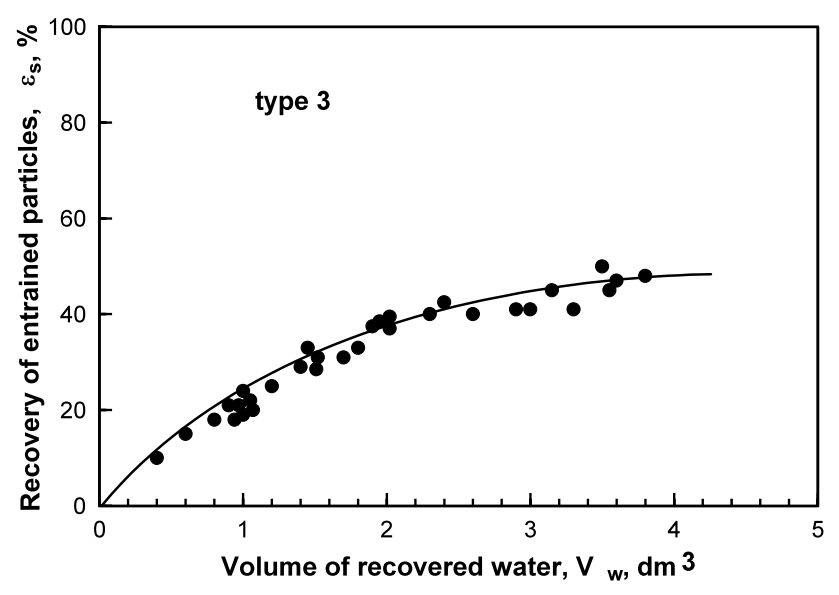

Fig. 6 Type 3 of entrainment separation curve. Results of batch flotation with water addition for $-40 \mu \mathrm{m}$ quartz in the presence of PPG frother in a Denver laboratory machine $\left(3 \mathrm{dm}^{3}\right.$ ) (after Kirjavainen 1989, 1992b, 1996)

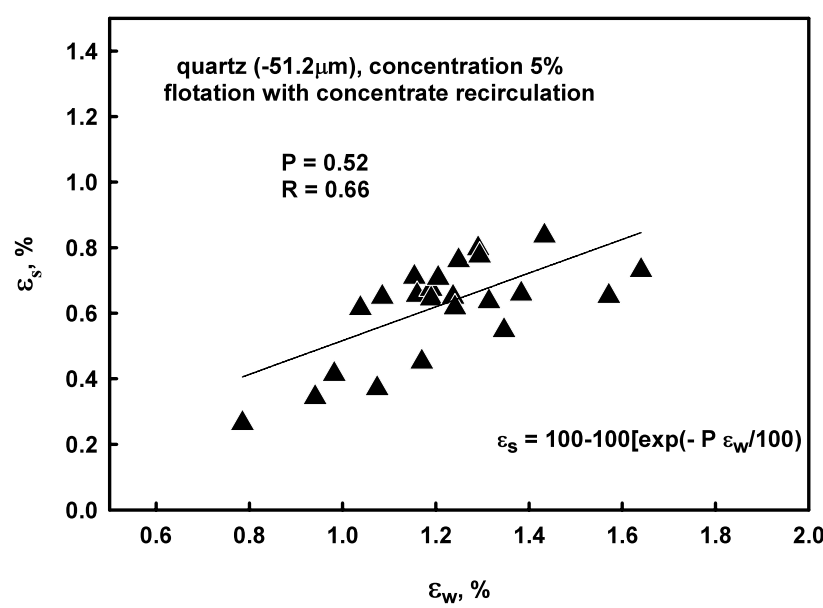

Fig. 7 Type 3 of entrainment separation curve. Flotation with circulation of froth product for $(-51.2 \mu \mathrm{m})$ quartz in the presence of PPG frother in a Denver laboratory machine $\left(3 \mathrm{dm}^{3}\right)$. The plot is based on numerical values of Kirjavainen (1992b) reported in Appendix $D$ of his work

$(1989,1992 \mathrm{a}, 1992 \mathrm{~b})$ proposed the following relation between $\varepsilon_{s}$ and $\varepsilon_{w}$ for type 3 separation entrainment curves:

$\varepsilon_{s}=100-100\left[\exp \left(-\frac{\varepsilon_{w}}{100} \cdot P\right)\right]$

Equation (4) allows to define another entrainment separation coefficient which after Kirjavainen (1989, 1992a, 1992b) can be called $P$ :

$P=\frac{-\ln \left(\frac{100-\varepsilon_{s}}{100}\right)}{\frac{\varepsilon_{w}}{100}}$

where $P$ is a dimensionless entrainment separation coefficient which is independent of $\varepsilon_{s}$ and $\varepsilon_{w}$.
Table $3 Z$ values for different size fractions of silica during entrainment in continuous pilot scale flotation in an Agitair \# 8 flotation machine (Johnson et al. 1974)

\begin{tabular}{ll}
\hline$Z$ & Particle size \\
\hline $0.51-0.71$ & $0.0-11.0 \mu \mathrm{m}$, pulp density $17 \%$ \\
$0.02-0.11$ & $33.0-44.0 \mu \mathrm{m}$, pulp density $17 \%$ \\
$0.51-0.83$ & $0.0-11.0 \mu \mathrm{m}$, pulp density $17 \%-42 \%$ \\
\hline
\end{tabular}

In (4) and (5), similarly to other so far used relations, $\varepsilon_{s}$ denotes recovery of particles in the froth product and $\varepsilon_{w}$ represents recovery of water in the froth product, both in $\%$. The values of $P$ for quartz, for which the results of mechanical flotation were presented in Fig. 7, is equal to 0.52. Theoretically $P$ can assume the values from 0 to 1 .

In some studies the plateau is less than $100 \%$ and is called the maximum recovery $\left(\varepsilon_{s} \max \right)$. Therefore, type 3 of the entrainment separation curve can also be approximated with exponential equations. Basing on the report of Gulsoy (1999) it is possible to apply an equation similar to the kinetics of flotation in which time is replaced with water recovery or parameter proportional to water recovery:

$\varepsilon_{s}=\varepsilon_{s \max }\left(1-\exp \left(-\frac{k \varepsilon_{w}}{100}\right)\right)$.

Such approach has a deficiency because entrainment has to be characterized with two parameters $\left(\varepsilon_{s} \max\right.$ and $k$ ). Another approach was tested by Drzymala and Hrycyna (2004). They characterized the entrainment using only $\varepsilon_{s}$ max while parameter $k$ was ignored. Their entrainment separation curves were plotted as particle recovery versus flotation time as a parameter being proportional to $\varepsilon_{w}$ (Fig. 8). The $\varepsilon_{s \text { max }}$ values for the investigated hydrophilic materials 40 $50 \mu \mathrm{m}$ in size after a long time of bubbling in a Mechanobr laboratory flotation machine were: quartz $44.9 \%$, gypsum 52.5\%, sapropelic coal 99.9\% (Hrycyna 1999). Mechanobr and Denver flotation machines are similar in design but the Mechanobr device is smaller in size.

\subsection{Type 4}

Entrainment expressed as recovery of particles versus recovery of water can be parabolic in character. It represents type 4 of entrainment separation curves (Fig. 3). Such a shape was observed by Lynch et al. (1974) as well as Bisshop and White (1976). Figure 9 presents the results of Engelbrecht and Woodburn (1975), who investigated quartz and pyrite entrainment as a function of amount of recovered water. Water entrainment was controlled either by aeration rate or froth height. 


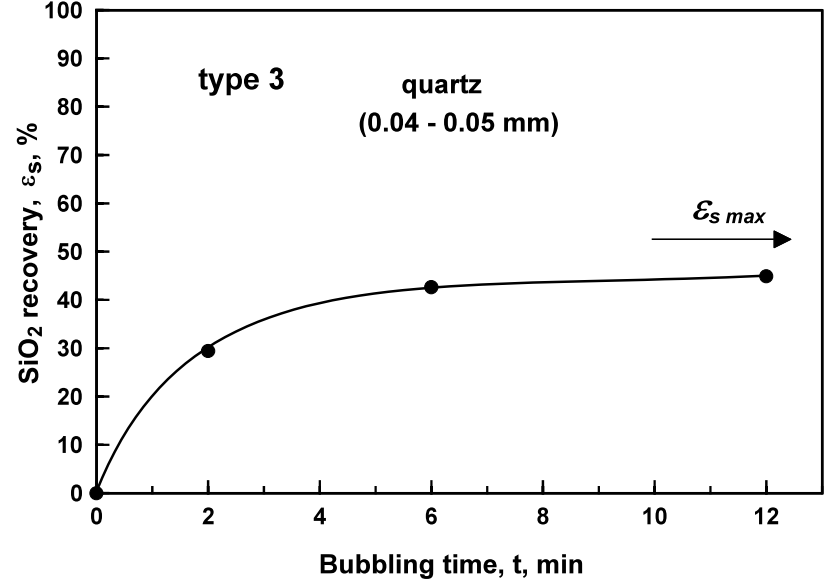

Fig. 8 Kinetics of entrainment for a narrow size fraction of quartz $(0.04-0.05 \mathrm{~mm})$ recorded for flotation in the presence of $\alpha$-terpineol as frother in a Mechanobr laboratory flotation machine, $200 \mathrm{~cm}^{3}$ cell (after Drzymala and Hrycyna 2004)

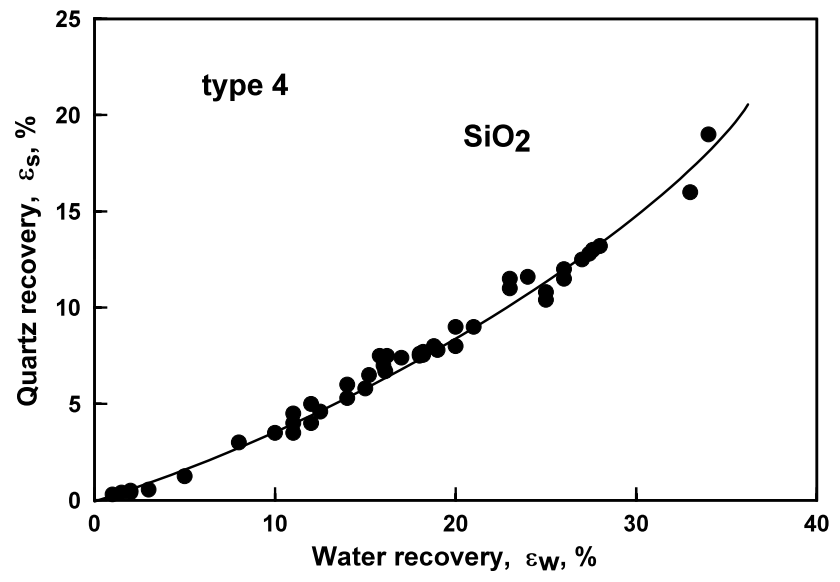

Fig. 9 Relationship between recovery of quartz particles and water recovery. The relation represents type 4 of entrainment separation curve. Experiments were performed in a flotation machine equipped with $30 \mathrm{dm}^{3}$ flotation cell. Frother: Dowfroth 250 (after Engelbrecht and Woodburn 1975)

According to Laplante et al. $(1980,1989)$ type 4 curve can be approximated with formula:

$\varepsilon_{s}=\frac{100 \cdot Z \cdot \varepsilon_{w}}{100+\varepsilon_{w}(Z-1)}$

where $Z$ is called the classification entrainment coefficient which may assume the values between 0 and 1 . Rearrangement of (7) provides a definition of classification entrainment coefficient $Z$ :

$Z=\frac{\varepsilon_{s}}{100-\varepsilon_{s}} \cdot\left(\frac{100}{\varepsilon_{w}}-1\right)$

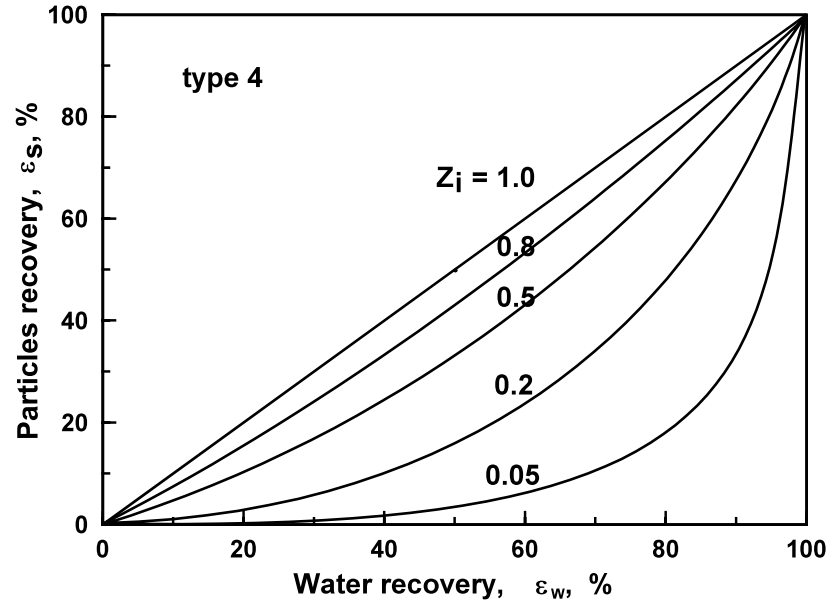

Fig. 10 Entrainment separation curves depending on the value of entrainment separation coefficient $Z$ (after Laplante et al. 1989)

The plot shown in Fig. 10 resembles typical Fuerstenau's separation curves (Drzymala and Ahmed 2005), which shape is regulated by the value of parameter $Z$.

The entrainment separation coefficient $Z$ can be expressed by the formula:

$Z=\frac{\left(\begin{array}{l}\text { mass of free gangue particles } \\ \text { per unit mass of water }\end{array}\right)_{\text {concentrate }}}{\left(\begin{array}{l}\text { mass of free gangue particles } \\ \text { per unit mass of water }\end{array}\right)_{\text {pulp }}}$.

Frequently not $Z$ but $C F_{i}$ symbol is used (Johnson et al. 1974; Lynch et al. 1974; Savassi et al. 1998; Vera et al. 2002; Bisshop and White 1976). Table 3 provides $Z$ values for silica determined by Johnson et al. (1974).

The shape of type 4 curves can be approximated with many other mathematical formulas (Drzymala and Ahmed 2005).

When the pulp contains not only liberated but also intergrowths of hydrophilic and hydrophobic particles, there is a need to use modified entrainment separation coefficients. For instance coefficient $X$, a modification of coefficient Z, has the form (Ross 1991b; Savassi et al. 1998; Lynch et al. 1974):

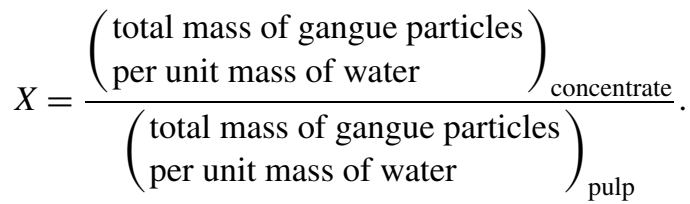

\subsection{Type 5}

According to Warren (1985) as well as Smith and Warren (1989) type 5 of the entrainment separation curve is observed in flotation systems in which particles float by en- 


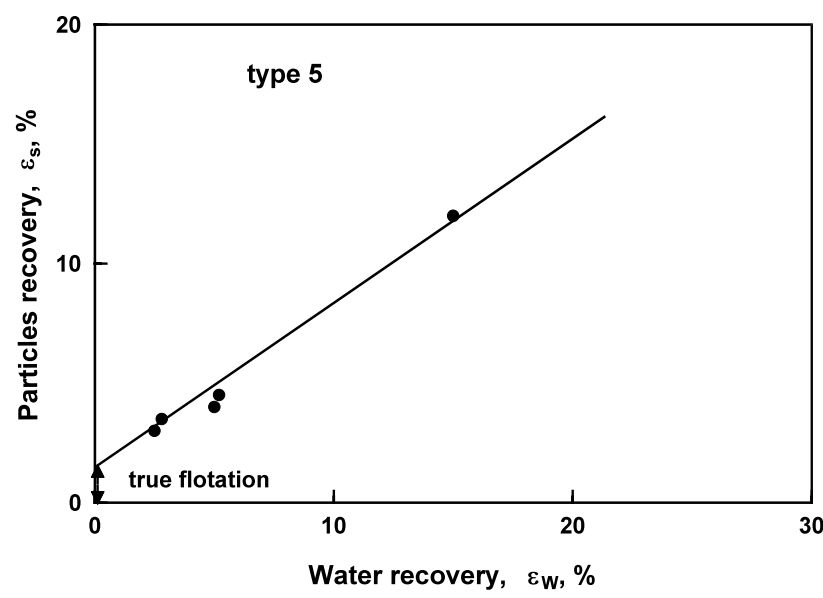

Fig. 11 Type 5 of entrainment separation curve for relating recovery of water and particles. Based on Laplante et al. (1989) and Warren (1985)

trained and true flotation. The intercept of the particles recovery line with the y axis (Fig. 11) indicates the recovery due to true flotation. Type 5 of the entrainment separation curve was reported for instance by Livshits and Bezrodnaya (1961), Engelbrecht and Woodburn (1975), Warren (1985), Smith and Warren (1989), and Laplante et al. (1989).

The equation (Warren 1985; Smith and Warren 1989) which can be used for determination of the entrainment coefficient is:

$\varepsilon_{s}=\varepsilon_{f}+g \varepsilon_{w}$,

where $\varepsilon_{f}$ stand for recovery of particles due to true flotation and $g$ is the entrainment slope.

\section{Conclusions}

On the basis of literature data five types of entrainment upgrading curves relating recovery of fine particles and water recovery can be distinguished: linear (type 1), linear shifted down (type 2), reaching plateau (type 3), increasing (type 4) and linear shifted up (type 5). Their shape depends on the methodology of flotation. The plots are useful for determination of appropriate equations and coefficients characterizing the entrainment process.

Acknowledgement The paper was partially financed by Polish Government grant \# 343165 and 343066 .

Open Access This article is distributed under the terms of the Creative Commons Attribution Noncommercial License which permits any noncommercial use, distribution, and reproduction in any medium, provided the original author(s) and source are credited.

\section{References}

Bisshop, J.P., White, M.E.: Study of particle entrainment in flotation froths. Trans. Inst. Min. Metall. 85, C191-194 (1976)

Drzymala, J., Ahmed, H.: Mathematical equations for approximation of separation result using the Fuerstenau upgrading curves. Int. J. Miner. Process. 76(1/2), 55-65 (2005)

Drzymala, J., Hrycyna, E.: Entrainment of particles in the Mechanobr laboratory flotation machine. Gornictwo i Geologia VII, Prace Naukowe Instytutu Gornictwa PWr. 106. Studia i Materialy, vol. 30, Wroclaw (2004)

Engelbrecht, J.A., Woodburn, E.T.: The effects of froth height aeration rate and gas precipitation on flotation. J. S. Afr. Inst. Min. Metall. 76(3), 125-132 (1975)

Goodman, R.H., Trahar, W.J.: Flotation of cassiterite at the Renison Tin Mine. Renison Bell, Tasmania. Int. Tin Symp., La Paz, Bolivia, Nov. 1977

Gulsoy, O.Y.: An Evaluation of the entrainment modelling approaches in flotation. Madencilik 38(1), 13-30 (1999)

Hrycyna, E.: Entrainment in the Mechanobr mechanical laboratory flotation machine. Master thesis, Mining Department, Wroclaw University of Technology (1999) (in Polish)

Johnson, N.W., McKee, D.J., Lynch, A.J.: Flotation rates of nonsulfide minerals in chalcopyrite flotation processes. Trans. AIME 256, 204-209 (1974)

Jowett, A.: Gangue mineral contamination of froth. Brit. Chem. Eng. 11, 330-333 (1966)

Kirjavainen, V.M.: Application of a probability model for the entrainment of hydrophilic particles in froth flotation. In. J. Miner. Process. 27, 63-74 (1989)

Kirjavainen, V.M.: Mathematical model for the entrainment of hydrophilic particles in froth flotation. Int. J. Miner. Process. 35, $1-11(1992 a)$

Kirjavainen, V.M.: Study on Entrainment Mechanism in Dispersed Flotation Suspensions. Chemical Technology and Metallurgy Series, vol. 206, Helsinki (1992b)

Kirjavainen, V.M.: Review and analysis of factors controlling the mechanical flotation of gangue minerals. Int. J. Miner. Process. 23, 33-53 (1996)

Kirjavainen, V.M., Laapas, H.R., Heiskanen, K.G.H.: The effect of some factors on the entrainment mechanism in froth flotation. Preprints of the XVII International Mineral Processing Congress, Dresden, FRG, vol. 2, pp. 217-226 (1991)

Konopacka, Z.: Investigation on particles entrainment in flotation. Ph.D. thesis, Mining Department, Wroclaw University of Technology (2004) (in Polish)

Konopacka, Z.: Mechanical flotation. Oficyna Politechniki Wrocławskiej, Wroclaw (2005) (in Polish)

Laplante, A.R.: The effect of air flow rate on the kinetics of flotation. Ph.D. thesis, University of Toronto (1980)

Laplante, A.R., Kaya, M., Smith, H.W.: The effect of froth on flotation kinetics-a mass transfer approach. In: Laskowski, J.S. (ed.) Frothing in Flotation, vol. 5, pp. 147-168. Gordon and Breach, New York (1989)

Livshits, A.K., Bezrodnaya, R.M.: Velocity of entrainment of water and solids to froth product. Cvet. Met. 11, 14-16 (1961) (in Russian)

Lynch, A.J., Johnson, N.W., Manlapig, E.W., Thorne, G.C.: Mineral and Coal Flotation Circuits-Their Simulation and Control. Elsevier, Amsterdam (1981)

Lynch, A.J., Johnson, N.W., McKee, D.J., Thorne, G.C.: The behaviour of minerals in sulphide flotation process with reference to simulation and control. J. S. Afr. Inst. Min. Metall. 74(9), 349-360 (1974)

Maachar, A., Dobby, G.S.: Measurement of feed water recovery and entrainment solids recovery in flotation columns. Can. Metall. Q. 31(3), 167-172 (1992) 
Ross, V.E.: An investigation of sub-processes in equilibrium froths. II. The effect of operating conditions. Int. J. Miner. Process. 31, 5171 (1991a)

Ross, V.E.: Comparison of methods for evaluation of true flotation and entrainment. Trans. Inst. Min. Metall., Sec. C 100, C121-C126 (1991b)

Ross, V.E., Van Deventer, J.S.J.: Mass transport in flotation column froths. In: Sastry, K.V.S. (ed.) Column Flotation. Proceedings of an International Symposium SME-AIME Annual Meeting, Phoenix, Arizona, pp. 129-39 (1988)

Savassi, O.N., Alexander, D.J., Franzidis, J.P., Manlapig, E.V.: An empirical model for entrainment in industrial flotation plants. Min. Eng. 11(3), 243-256 (1998)

Smith, P.G., Warren, L.J.: Entrainment of particles into flotation froths. In: Laskowski, J.S. (ed.) Frothing in Flotation, pp. 123-145. Gordon and Breach, New York (1989)

Subrahmanyam, T.V., Forssberg, E.: Froth stability, particle entrainment and drainage in flotation-a review. Int. J. Miner. Process. 23, 33-53 (1988a)
Subrahmanyam, T.V., Forssberg, E.: Study of particle entrainment in flotation with different frothers-the case of copper ore. In: XVI International Mineral Processing Congress, pp. 785-795. Elsevier, Amsterdam (1988b)

Trahar, W.J.: A rational interpretation of the role of particle size in flotation. Int. J. Miner. Process. 8, 289-327 (1981)

Vera, M.A., Mathe, Z.T., Franzidis, J.P., Harris, M.C., Manlapig, E.V., O'Connor, C.T.: The modelling of froth zone recovery in bath and continuously operated laboratory flotation cells. Int. Miner. Process. 64, 135-151 (2002)

Waksmundzki, A., Neczaj-Hruzewicz, J., Ptanik, M.: Mechanism of carryover of gangue slimes during flotation of sulphur. Trans. Inst. Min. Metall., Sec. C 81, C249-251 (1972)

Warren, L.J.: Determination of the contributions of true flotation and entrainment in batch flotation tests. Int. J. Miner. Process. 14, 33 44 (1985)

Wojcik, W., Waksmundzki, A., Chibowski, E., Czarkowski, H.: Entrainment of slimes in coal flotation. Przem. Chem. 52, 826-828 (1973) (in Polish) 